УДК 550.31

H. Guliyev, Dr. Sci. (Phys.-Math.), Prof., Academician of ANAS Head of department "Tectonophysics and Geomechanics" E-mail: hatamguliyev@gmail. com, tel.: (+994 12) 5105617 Institute of Geology and Geophysics of ANAS 119 H. Javid Ave., Baku, AZ1143, Azerbaijan

\title{
THE FEATURES OF THE PROPAGATION OF ELASTIC WAVES IN ISOTROPIC MEDIA AT HIGH AND ULTRA-HIGH PRESSURES
}

\footnotetext{
(Рекомендовано членом редакційної колегї д-ром фіз.-мат. наук, проф. Б.П. Масловим)
}

Studies of problems of the propagation of elastic waves in the geological medium constitute the scientific basis of the processing and interpretation of dataset of seismic exploration and seismological works.

Objective. Creation of a more grounded theoretical basis of the geomechanical interpretation of various groups of geophysical observational and experimental data.

Methodology. Nonclassical-linearized approach of non-linear elastodynamics. Linear and nonlinear small and large initial deformations are taken into account. The strain processes are described applying various elastic potentials.

Results. Analytical dependences of the parameters of pressure and velocities of propagation of elastic waves on deformations without additional linearization are obtained within the framework of various versions of the theory of small and initial deformations using the quadratic and elastic potentials of the Murnaghan type.

Scientific novelty. It is established that there are critical values of deformation while reaching them elastic pressure and shear waves with true velocity cannot propagate in uniformly deformed elastic isotropic media. The quantitative values of the critical values of deformations for pressure and shear waves differ, and essentially depend on the applied elastic potentials.

Practical significance. The obtained analytical dependences allow synthesizing the true values of the elastic parameters of the deformed media from seismic exploration and seismological dataset. The establishment of critical deformations for velocities of pressure and shear waves will make it possible to suggest differential criteria of the distribution of elastic parameters in theoretical models of the Earth in its various structural elements as a whole and separately.

Keywords. Nonlinear elastodynamics, elastic waves, initial deformation, velocities of pressure and shear waves.

Introduction. The nonclassical-linearized approach (NLA) of nonlinear elastodynamics has been greatly developed in studies of problems of the mechanics of a deformed solid body in the last few decades $[4,5,10,11,16$, $18,21,37]$. Later the NLA was applied to study various problems of geology, geophysics, mining, etc. [1, 3, 6-9, 11, $19,20,26]$. The problems are considered in all these studies excluding separate papers in case of the ratio of the pressure parameter $P$ to the shear modulus $\mu$ is much less than unit. Based on this circumstance, a direction is developed in the NLA where after the linearization of all the equations and correlations in a small neighborhood of the disturbed state (both at small and large initial deformations), linearization is also additionally carried out in terms of the parameter $\frac{P}{\mu}$.

This constraint is not adequate with both practically [2, $12,13]$ and experimentally observed result $[14,29,30,32$, 33] in large classes of problems of geology and geophysics. In particular, the distribution of physico-mechanical as well as elastic parameters of the Earth are obtained in the theoretical structural and dynamic models of the Earth [2,

$12,13,15,17,22-25,27,28,31,34-36,38]$ while violating the condition of smallness of the indicated correlation.

It is shown that, the basic requirements of the mechanics of the deformable solid body relating to the strength, stability and propagation of elastic waves with true velocity are violated in the process of the generally accepted distribution of the elastic parameters of the medium and pressure in the inner solid core of the Earth applying the NLA (under the conditions $\frac{P}{\mu}<<1$ ) in [20]. In this connection, it is of scientific and applied interest to study the character of changes of parameters of propagation of velocities of elastic waves and pressures as a function of changes of strains within the NLA under the conditions of removing the constraints $\frac{P}{\mu}<<1$ which are important for the problems of geophysics of deep depths. Theoretical results are used for this purpose $[4,5]$.

Materials and methods. Let'sconsider an unbounded elastic space subject to homogeneous deformation in the Lagrangian coordinate system $x_{n}=x_{n}^{1}$ coinciding in the natural state with Cartesian coordinates.

$$
u_{m}^{0}=\left(\lambda_{m}-1\right) \lambda_{m} ; \lambda_{m}=\text { const, } m=1,2,3 \text {. }
$$

Where $u_{m}^{0}$ are components of the displacement vector of the initial-deformedstate, and $\lambda_{m}$ are coefficients of elongation (shortening) along the coordinate axes.

Further, let's consider the problems on the propagation of elastic waves in a previously deformed isotropic space under the conditions (1)-(3).

$$
\omega_{i j \alpha \beta} \frac{\partial^{2} u_{\alpha}}{\partial x_{i} \partial x_{\beta}}-\rho \frac{\partial^{2} u_{j}}{\partial t^{2}}=0, \quad \omega_{i j \alpha \beta}=\text { const . }
$$

In case of the theory of large initial deformations

$$
\omega_{i j \alpha \beta}=\lambda_{j} \lambda_{\alpha}\left[\delta_{i j} \delta_{\alpha \beta} A_{i \beta}+\left(1-\delta_{i j}\right)\left(\delta_{i \alpha} \delta_{j \beta}+\delta_{i \beta} \delta_{j \alpha}\right) \mu_{i j}\right]+\delta_{i \beta} \delta_{j \alpha} S_{\beta \beta}^{0}
$$

For the theory of small initial deformations according to the first and the second versions of the theory

$$
\omega_{i j \alpha \beta}=\lambda_{j} \lambda_{\alpha}\left[\delta_{i j} \delta_{\alpha \beta} A_{i \beta}+\left(1-\delta_{i j}\right)\left(\delta_{i \alpha} \delta_{j \beta}+\delta_{i \beta} \delta_{j \alpha}\right) \mu_{i j}\right]+\delta_{i \beta} \delta_{j \alpha} \sigma_{\beta \beta}^{0},
$$




$$
\omega_{i j \alpha \beta}=\delta_{i j} \delta_{\alpha \beta} A_{i \beta}+\left(1-\delta_{i j}\right)\left(\delta_{i \alpha} \delta_{j \beta}+\delta_{i \beta} \delta_{j \alpha}\right) \mu_{i j}+\delta_{i \beta} \delta_{j \alpha} \sigma_{\beta \beta}^{0} .
$$

The following correlations $[4,5]$ are obtained considering elastic waves propagating along the axis $o x_{1}$ according to the equation (4) in case of the theory of large initial deformations

$$
\begin{gathered}
\rho C_{l x_{1}}^{2}=\lambda_{1}^{4} A_{11}+\lambda_{1}^{2} S_{11}^{0} ; \rho C_{s x_{2}}^{2}=\lambda_{1}^{4} \lambda_{2}^{2} \mu_{12}+\lambda_{1}^{2} S_{11}^{0}, \\
\rho C_{s x_{3}}^{2}=\lambda_{1}^{4} \lambda_{2}^{2} \mu_{13}+\lambda_{1}^{2} S_{11}^{0} .
\end{gathered}
$$

In case of the second variant of the theory of small initial deformations

$$
\rho V_{l x_{1}}^{2}=\lambda_{1}^{2}\left(A_{11}+\sigma_{11}^{0}\right) ; \rho V_{s x_{2}}^{2}=\lambda_{1}^{2}\left(\mu_{12}+\sigma_{11}^{0}\right) ; \rho V_{s x_{3}}^{2}=\lambda_{1}^{2}\left(\mu_{13}+\sigma_{11}^{0}\right)
$$

The structure of the values $A_{i \beta}, \mu_{i j}$ and $S_{\beta \beta}^{0} \quad\left(\operatorname{or} \sigma_{\beta \beta}^{0}\right.$ ) for each version of the problem statements is concretized by the definition of the correlations of the elasticity of the nonlinear theory (elastic potentials) in the correlations (3)(5). Specific expressions of these values for the simplest elastic potentials are given in [4, 5, 21]. In the expressions (2) $-(7), u_{i}(i=1,2,3)$ are the components of the perturbation of displacements, $S_{\beta \beta}^{0}$ are the components of the stress tensor assigned to a unit of an area in the initial-deformed state, $\sigma_{i i}^{0}$ is the stress tensor component assigned to a unit of an area in the natural state, $\rho$ is the medium density and $\delta_{i j}$ are the Kronecker symbols. It is easy to obtain analogous formulae in case of the propagation of elastic waves along other coordinate axes through cyclic permutations of the indices in (8) and (9).

The experimentally observed acoustoelastic effect (of various kind of reactions, velocities of polarized shear waves on the action of initial deformations) in comparatively solid compressible media is described using elastic potentials in the structure of which, the third algebraic invariant of the Green's deformation tensor $[4,5]$ is also taken into account along with the first two. The simplest elastic potential corresponding to this requirement is a potential of the Murnaghan type. Thereby, the results concerning the potential of the Murnaghan type are given below.

In this case for all variants of the theory of initial deformations $[4,5]$

$$
\begin{aligned}
A_{i \beta} & =\lambda+2 a \varepsilon_{n n}^{0}+2 b\left(\varepsilon_{i i}^{0}+\varepsilon_{\beta \beta}^{0}\right)+2 \delta_{i \beta}\left(\mu+b \varepsilon_{n n}^{0}+c \varepsilon_{i i}^{0}\right), \\
\mu_{i j} & =\mu+b \varepsilon_{n n}^{0}+\frac{1}{2} c\left(\varepsilon_{i i}^{0}+\varepsilon_{j j}^{0}\right), \quad \lambda, \mu, a, b, c=\text { const } .
\end{aligned}
$$

For theories of large initial pressure

$$
S_{\beta \beta}^{0}=\lambda \varepsilon_{n n}^{0}+2 \mu \varepsilon_{\beta \beta}^{0}+a\left(\varepsilon_{n n}^{0}\right)^{2}+2 b \varepsilon_{n n}^{0} \varepsilon_{\beta \beta}^{0}+b\left(\varepsilon_{n n}^{0}\right)^{2}+c\left(\varepsilon_{\beta \beta}^{0}\right)^{2},
$$

where $\lambda, \mu$ are Lame's elasticity moduli, $a, b, c$ are the elasticity moduli of the third order.

There are correlations for the first and the second version of the theory of small initial deformations correspondingly

$$
\begin{gathered}
\sigma_{\beta \beta}^{0}=\lambda \varepsilon_{n n}^{0}+2 \mu \varepsilon_{\beta \beta}^{0}+a\left(\varepsilon_{n n}^{0}\right)^{2}+2 b \varepsilon_{n n}^{0} \varepsilon_{\beta \beta}^{0}+b\left(\varepsilon_{n n}^{0}\right)^{2}+c\left(\varepsilon_{\beta \beta}^{0}\right)^{2}, 2 \varepsilon_{i j}^{0}=\delta_{i j}\left(\lambda_{j}^{2}-1\right), \\
\sigma_{\beta \beta}^{0}=\lambda \varepsilon_{n n}^{0}+2 \mu \varepsilon_{\beta \beta}^{0}+a\left(\varepsilon_{n n}^{0}\right)^{2}+2 b \varepsilon_{n n}^{0} \varepsilon_{\beta \beta}^{0}+b\left(\varepsilon_{n n}^{0}\right)^{2}+c\left(\varepsilon_{\beta \beta}^{0}\right)^{2}, \varepsilon_{i j}^{0}=\delta_{i j}\left(\lambda_{j}-1\right) .
\end{gathered}
$$

Formulae (6) and (7) considering the correlations (8)(12) allow studying the behavior of the parameters of velocities of propagation of elastic waves in isotropic compressible solid media depending on the nature of the change of random value of homogeneous deformations within the theory of large and two versions of the theory of small initial deformations. These formulae and correlations are obtained and applied to solve various specific problems of mechanics in $[4,5,21]$.An additional linearization is carried out in the expressions of formulae (10)-(12) eliminating nonlinear terms with respect to deformations in the study of specific problems based on practical mechanical arguments.

Pressure $P$ with stress are related to the following correlations [21] for the theory of large, first and the second variants of small initial deformations

for the theory of large and the first version of small initial states

$$
P_{\beta}^{0}=\lambda_{\beta} S_{\beta \beta}^{0} ; P_{\beta}^{0}=\lambda_{\beta} \sigma_{\beta \beta}^{0} ; P_{\beta}^{0}=\sigma_{\beta \beta}^{0} .
$$

The nonlinear character of the dependence of the basic parameters of the medium on the change of strains. Normal components of stress tensor within the theory of large and small initial strains within the NLA are determined according to the equations (10)-(12).

Let's consider the case of overall deformation for clarity and simplicity of statement especially in problems of geomechanics of large depths of overall deformation, i.e. $\varepsilon_{11}^{0}=\varepsilon_{22}^{0}=\varepsilon_{33}^{0}=\varepsilon_{0}$ is the most important case. At the same time we get from correlations (10)-(12) considering (13):

$$
P_{0}=\left(1+2 \varepsilon_{0}\right)^{\frac{1}{2}}\left[3 K_{0} \varepsilon_{0}+(9 a+15 b+c) \varepsilon_{0}^{2}\right] ; K_{0}=\lambda+\frac{2}{3} \mu,
$$

for the second version of the theory of small initial deformation states

$$
P_{0}=3 K_{0} \varepsilon_{0}+(9 a+15 b+c) \varepsilon_{0}^{2}
$$


Using the correlations (6), (7) and (8)-(12) in case of overall homogeneous deformation to determine the dependence of the quasive locities of propagation of elastic waves on deformations considering the well-known correlations

$$
\begin{gathered}
\rho C_{l 0}^{2}=\lambda+2 \mu, \quad \rho C_{S 0}^{2}=\mu, \\
\rho V_{l 0}^{2}=\lambda+2 \mu, \quad \rho V_{S 0}^{2}=\mu,
\end{gathered}
$$

in case of the theory of large and the first version of small initial deformations we will get

$$
\begin{aligned}
& \left(\frac{C_{l x_{1}}}{C_{l_{0}}}\right)^{2}=1+\left[\frac{5-3 v}{1-v}+(\lambda+2 \mu)^{-1}(6 a+10 b+2 c)\right] \varepsilon_{0}+ \\
& +\left[\frac{2(3-v)}{(1-v)}+(33 a+55 b+9 c)(\lambda+2 \mu)^{-1}\right] \varepsilon_{0}^{2}+(\lambda+2 \mu)^{-1}(42 a+70 b+10 c) \varepsilon_{0}^{3}, \\
& \left(\frac{C_{s x_{2}}}{C_{S_{0}}}\right)^{2}=\left(\frac{C_{s x_{3}}}{C_{S_{0}}}\right)^{2}=1+\left[\frac{6(1-v)}{1-2 v}+\frac{1}{\mu}(3 b+c)\right] \varepsilon_{0}+ \\
& +\left[\frac{4(2-v)}{1-2 v}+\frac{1}{\mu}(9 a+27 b+5 c)\right] \varepsilon_{0}^{2}+\frac{1}{\mu}(18 a+42 b+6 c) \varepsilon_{0}^{3}, \\
& \left(\frac{V_{l x_{1}}}{V_{I_{0}}}\right)^{2}=1+\left[\frac{3-v}{1-v}+(\lambda+2 \mu)^{-1}(6 a+10 b+2 c)\right] \varepsilon_{0}+\left[\frac{3+v}{1-v}+(\lambda+2 \mu)^{-1}(21 a+35 b+5 c)\right] \varepsilon_{0}^{2}+ \\
& +\left[\frac{1+v}{1-v}+(\lambda+2 \mu)^{-1}(24 a+40 b+4 c)\right] \varepsilon_{0}^{3}+(\lambda+2 \mu)^{-1}(9 a+15 b+c) \varepsilon_{0}^{4}, \\
& \left(\frac{V_{S x_{2}}}{V_{S_{0}}}\right)^{2}=\left(\frac{V_{S x_{3}}}{V_{S_{0}}}\right)^{2}=1+\left[\frac{2(2-v)}{1-2 v}+\mu^{-1}(3 b+c)\right] \varepsilon_{0}+\left[\frac{5+2 v}{1-2 v}+\mu^{-1}(9 a+21 b+3 c)\right] \varepsilon_{0}^{2}+ \\
& +\left[\frac{2(1+v)}{1-2 v}+\mu^{-1}(18 a+33 b+3 c)\right] \varepsilon_{0}^{3}+\mu^{-1}(9 a+15 b+c) \varepsilon_{0}^{4} .
\end{aligned}
$$

Here $C_{l_{0}}$ and $C_{S_{0}}$ are the velocities of propagation of pressure and shear waves in the medium without initial deformations within the theory of large initial deformations accordingly; $V_{I_{0}}$ and $V_{S_{0}}$ are the same within the second version of the theory of small initial deformations. In the correlations (18)-(21), $v$ - is Poisson's ratio of the material. The parameters of pressure and shear waves within the theory of large - the first version of the theory of small and the second version of the theory of small initial deformations are defined with values $\left(\frac{C_{l x_{1}}}{C_{l_{0}}}\right)^{2},\left(\frac{C_{s x_{2}}}{C_{s_{0}}}\right)^{2}$ and $\left(\frac{V_{l x_{1}}}{V_{l_{0}}}\right)^{2}$, $\left(\frac{V_{s x_{2}}}{V_{s_{0}}}\right)^{2}$ in the paper accordingly.
In case of the quadratic elastic potential in the formulae (14), (15) and (18)-(21), it is necessary to consider $a=b=c=0$.

Initial data for numerical experiments. The structures of formulae (14), (15) and (18)-(21) allow performing calculations for the entire interval of variation of the Poisson's ratio $0<v<0,5$ in case of using the quadratic elastic potential. In case of applying an elastic potential of the Murnaghan type for performing specific calculations, it is also necessary to have information on the elasticity moduli of the second $(\lambda, \mu)$ and the third $(a, b, c)$ orders.

The necessary initial data for a number of materials are shown in Table 1. Data for plexiglas and steel 092c are taken from [4], and data for plagiogranite are taken from [8]. The data related to the theory of large initial deformations are given in the numerator and the data related to the second version of the theory of small initial deformations are given in the denominator. The dashes in the plagiogranite column indicate lack of data for this case.

Table 1. The necessary initial data for a number of materials

\begin{tabular}{|c|c|c|c|c|c|c|}
\hline $\begin{array}{c}\text { Medium } \\
\text { parameters }\end{array}$ & $10^{-3} \mathrm{a}, \mathbf{M P a}$ & $10^{-3} b, \mathbf{M P a}$ & $10^{-3} c, \mathbf{M P a}$ & $10^{-3} \lambda, \mathbf{M P a}$ & $10^{-3} \mu, \mathbf{M P a}$ & $v$ \\
\hline Plexiglas & $\frac{-3,99}{0,268}$ & $\frac{-7,16}{-3,12}$ & $\frac{-14,4}{-6,77} 8$ & 4,04 & 1,9 & 0,3401 \\
\hline Steel & $\frac{-325}{-269}$ & $\frac{-309}{-214}$ & $\frac{-799}{-483}$ & 94,4 & 79,0 & 0,2722 \\
\hline Plagiogranite & $\frac{-3,87}{-}$ & $\frac{-1,99}{-}$ & $\frac{-6,24}{-}$ & 39,95 & 26,63 & 0,1999 \\
\hline
\end{tabular}

Results and discussion. Graphs of change of the parameters of pressure and shear elastic waves in plexiglas (red color), steel 092C (green color) and plagiogranite (blue color) depending on the growth of compression 
deformations are shown in Fig. 1-2. These calculations are performed using the quadratic elastic potential. Similar results calculated using an elastic potential of the Murnaghan type are shown in Fig. 3, 4. Comparison of the results in Fig. 1-2 with Fig. 3-4 show that the results obtained using various elastic potentials differ quantitatively. In this case, it is necessary to give preference to results
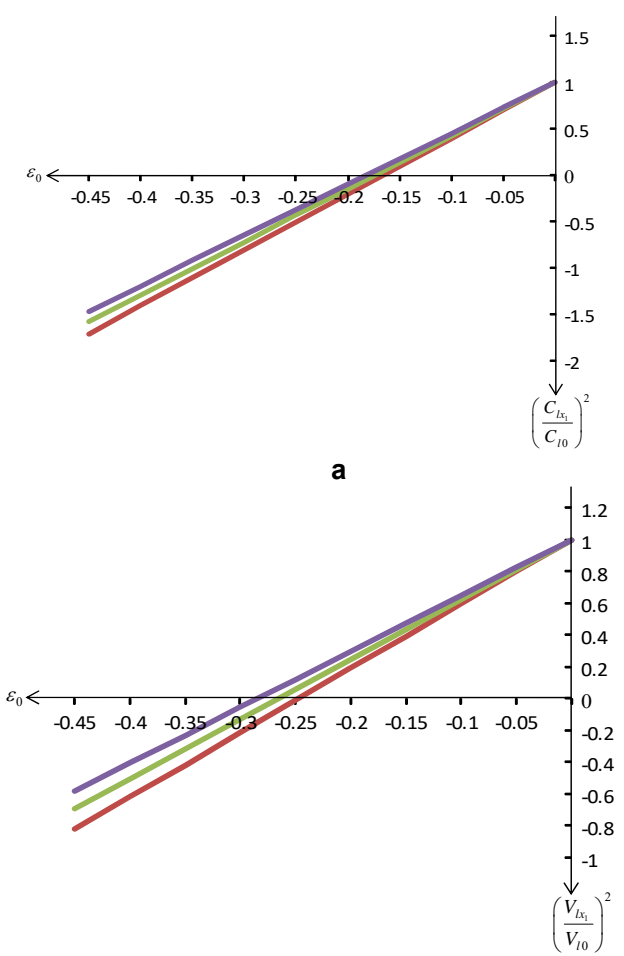

c corresponding to the potential of the Murnaghan type, since it is known that [4] the use of this potential allows correctly describing the acoustoelastic effect. The character of the change of parameters of pressure and shear waves fundamentally differ within the framework of linear and nonlinear approximations due to the increase of the value of compression deformation.

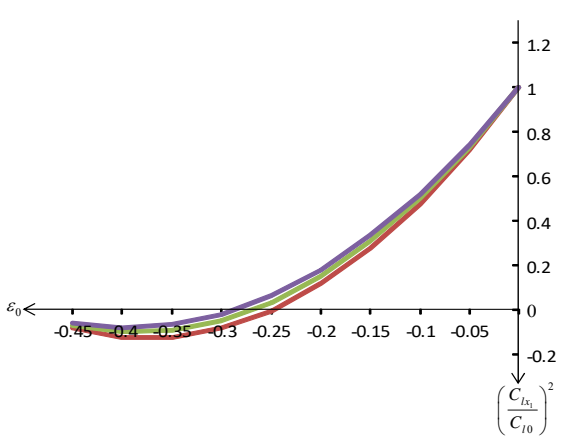

b

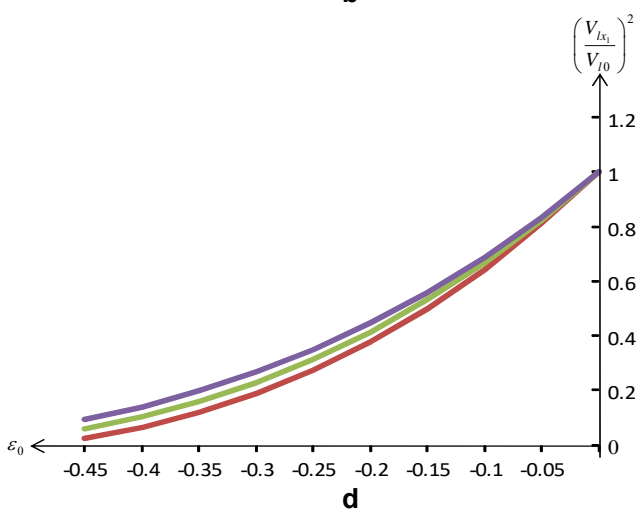

d

Fig. 1. Dependences of the parameter of elastic waves pressure on the growth of values of compression strains: a - equation (18) considering linear constituents, $b$ - equation (18) considering all the constituents within the theory of large and the first variation of small initial strains, $c$ - equations $(20)$ considering the linear constituents, $d$ - equations (20) considering all the constituents within the second version of the theory of small initial strains (in calculations $a=b=c=0$ )

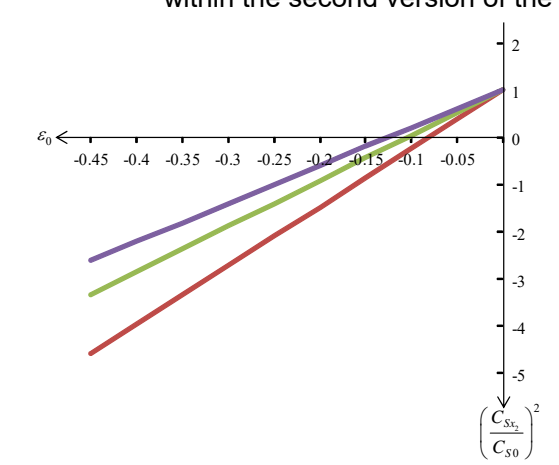

a

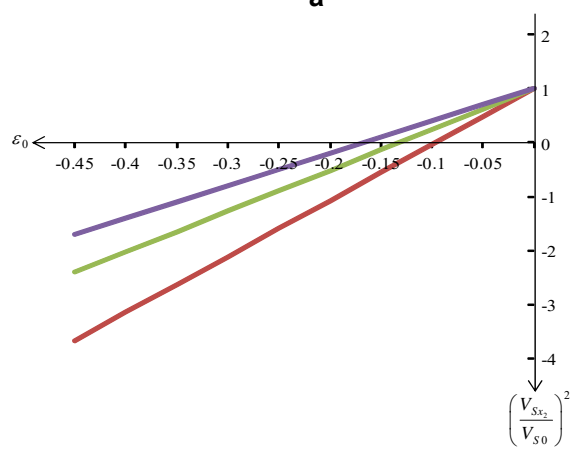

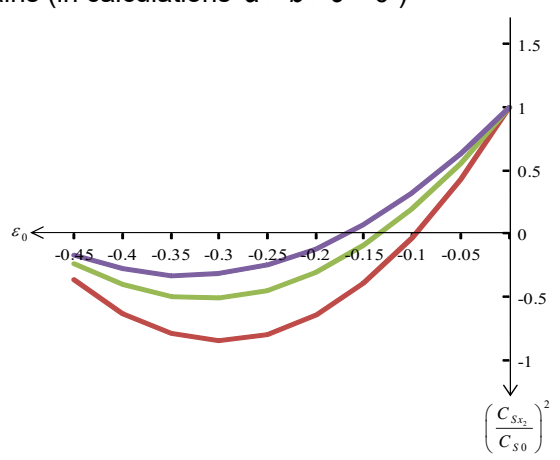

b

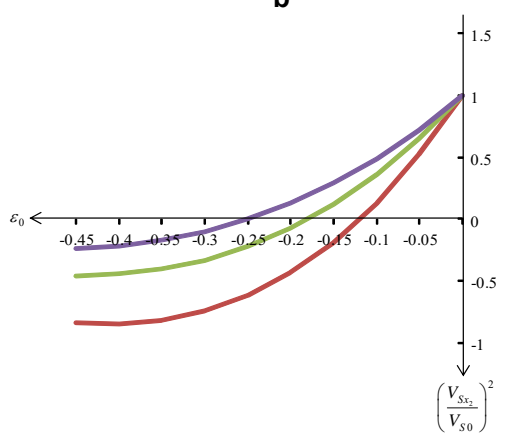

d

Fig. 2. Dependences of the parameter of shear elastic waves on the increase of values of compression deformations: $a$ - equation (19) considering only linear constituents, b - equation (19) considering all the constituents within the theory of large and the first version of the theory of small initial deformations, $c$ - equation (21) considering only linear constituents, $d$ - equation (21) considering all the constituents within the second variation of the theory of small initial deformations (in calcualtions $a=b=c=0$ ) 


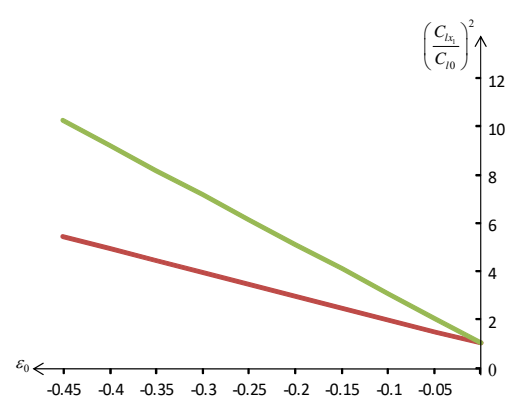

a

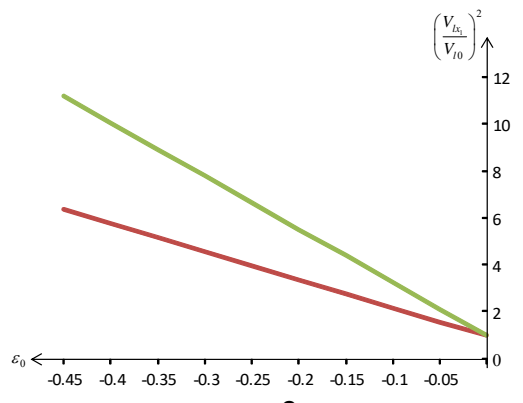

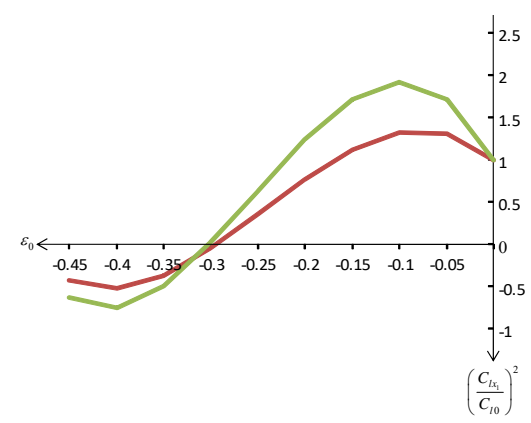

b

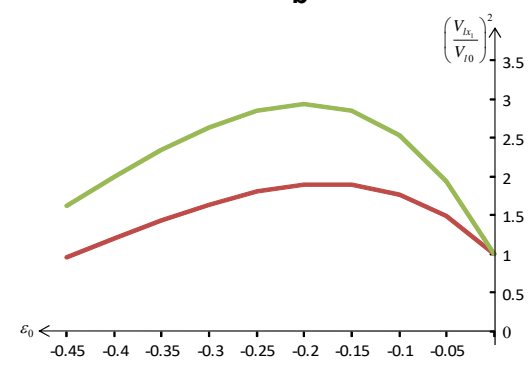

d

Fig. 3. Dependences of the parameter of elastic waves pressure on the increase of the values of compression deformations: $a$ - equation (18) considering only linear constituents, $b$ - equation (18) considering all the constituents within the theory of large and the first version of the theory of small initial deformations, c - equation (20) considering only linear constituents, $d$ - equation (20) considering all the constituents within the second version of the theory of small initial deformations
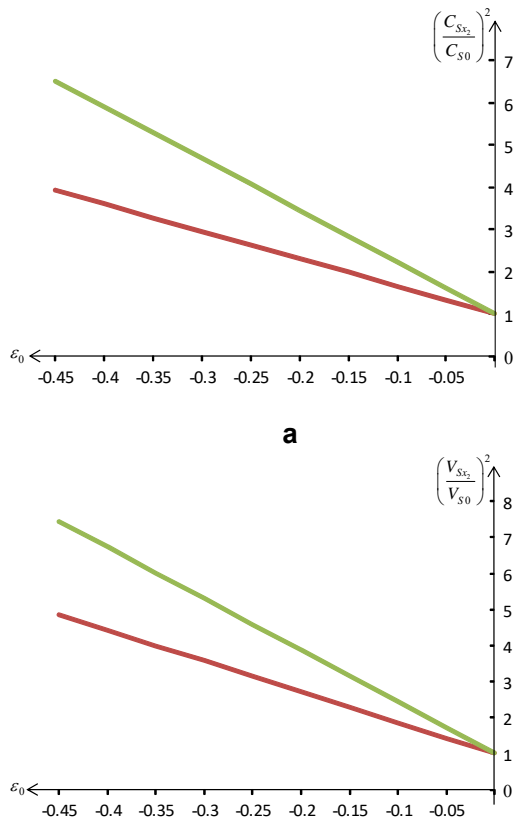

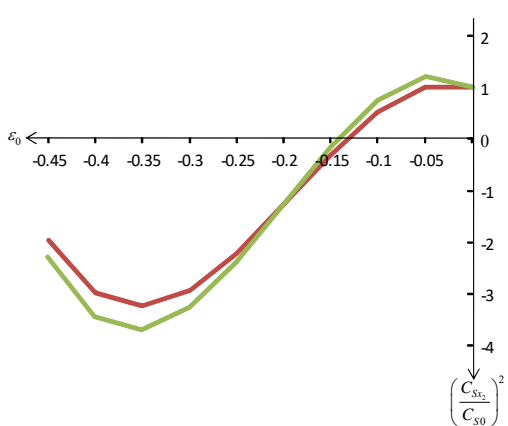

b

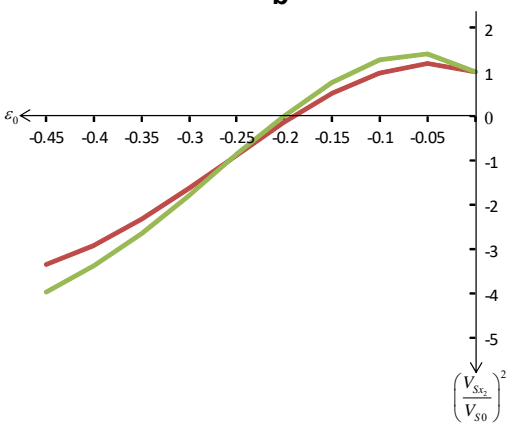

d

Fig. 4. Dependences of the parameter of elastic waves pressure on the increase of the values of compression deformations: a - equation (19) considering only linear constituents, b - equation (19) considering all constituents within the theory of large and the first version of the theory of small initial deformations, $c$ - equation (21) considering only the linear constituents, $d$ - equation (21) considering all the constituents within the second version of the theory of small initial deformations

It follows from Fig. 1-4 that the values of the quasivelocities of pressure and shear waves decrease in case of quadratic elastic potentials both at small (taking into account both variants) and large initial deformations due to the increase of compression deformation. Such results do not describe available [4] experimental data. Similar results for the considered materials obtained within the framework of an elastic potential of the Murnaghan type show fundamentally different character of the change. The quasi- velocity of both pressure and shear waves increase for each concrete material up to a certain value of the deformation values of overall compression within the framework of all variants of the theory of initial deformations and types of elastic waves. Further, due to the increase of values of compression deformation, the values of the quasi-velocities of both types of volume waves continue to increase within the framework of linear approximations, and they decrease within the framework of nonlinear solutions. For both types 
of volume waves, there are critical values of the compression deformation while reaching them elastic waves with true velocity cannot propagate in the medium. Despite the quantitative difference in the increase of quasi-velocities in the initial stage of the increase of values of compression deformation, critical values of compression deformations are found in the further stages of deformations (at large deformations) within the framework of the considered versions of the theory of the quadratic potential.

Based on the obtained theoretical formulae and numerical results, the impossibility of propagation of elastic waves with true velocity in the deformed media can be explained as follows. Dimensions of stresses and elasticity moduli are the same. The quantitative values of velocities of propagation of elastic waves are determined in the form of certain ratios of the elasticity moduli to the medium density. In case of deformed media, the ratio of the values of stress tensor components to the density is caused by nonlinear actions of the medium by the velocity dimension. The levels of the normal components of the stress tensor reach values comparable to the elasticity moduli of the medium of propagation of elastic waves under high baric conditions. Therefore, the quasi-velocities of elastic waves can increase, decrease, and turn to zero in the process of deformation depending on the nature of the action and on the stress level.

Conclusions. The dependences of change of pressure, parameters characterizing the velocities of pressure and shear elastic waves on the increase of values of the compression deformation in elastic isotropic media are analyzed within the framework of linear and nonlinear approximations of the NLA of nonlinear elastodynamics involving various elastic potentials. The linear and nonlinear solutions obtained within the framework of various elastic potentials differ quantitatively and qualitatively. Consideration of large and nonlinear strains of compression made it possible to determine their critical values while reaching them elastic pressure and shear waves with true velocities cannot propagate in elastic isotropic media. These features manifested in the process of propagation of elastic waves in the deformed isotropic media have important theoretical and applied values in the development of structural and true models of the Earth. It is necessary to properly take them into account in the process of development and interpretation of the corresponding geophysical data.

\section{Список використаних джерел}

1. Александров К.С. Метод определения нелинейных упругих свойств горных пород / К.С. Александров, Г.Т. Продайвода, Б.П. Маслов // Докпады академии наук. - 2001. - № 380,1. - С. 109-112.

2. Буллен К.Е. Плотность Земли / К.Е. Буллен. - М. : Мир, 1978. $422 \mathrm{c}$.

3. Выжва С.А. Эфффективные упругие свойства нелинейных многокомпонентных геологических сред / С.А. Выжва, Б.П. Маслов, Г.Т. Продайвода // Геофиз. журн. - 2005. - № 27, 6. - С. 1012-1022.

4. Гузь А.Н. Упругие волны в телах с начальными напряжениями / А.Н. Гузь. - К. : Наук. думка, 1986. - 916 с.

5. Гузь А.Н. Упругие волны в телах с начальными (остаточными) напряжениями / А.Н. Гузь. - К. : А.С.К, 2004. - 672 с.

6. Кулиев Г.Г. Об амплитудных характеристиках упругих волн в напряженных средах / Г.Г. Кулиев, М.Д. Джаббаров // Докл. АНР. - 2000. № 370,4 . - С. $672-674$.

7. Маслов Б.П. Дисперсия и рассеяние упругих волн в трещиноватой геологической среде / Б.П. Маслов, Г.Т. Продайвода // Геофиз. журн. - 1998. - № 20, 2. - С. 47-55

8. Продайвода Г.Т. Математичне моделювання ефективних геофозичних параметрів / Г.Т. Продайвода, С.А. Вижва, І.В. Віршило. - К ВПЦ "Київський університет", 2012. - 287 с.

9. Продайвода Г.Т. Сейсмоминералогическая модель земной коры Украинского щита / Г.Т. Продайвода, В.Д. Омельченко, Б.П. Маслов // Геофиз. журн. - 2004. - № 26, 4. - С. 100-107.

10. Трусделл К. Первоначальный курс рациональной механики сплошных сред / К. Трусделл. - М. : Мир, 1975. - 592 с

11. AkbarovS.D. DynamicsofPre-StrainedBi-MaterialElasticSystems: LinearizedThree-DimensionalApproach / S.D. Akbarov. - Switzerland: Springer, 2015. - $1004 \mathrm{c}$.
12. Anderson D.L. New Theory of the Earth / D.L. Anderson. - New York Cambridge University Press, 2007 - 400 c.

13. Anderson O.L. Equations of State of Solids for Geophysics and Ceramic Science / O.L. Anderson. - New York : Oxford University Press, 1995. $-432 \mathrm{c}$

14. Antonangeli D. Sound velocity of $\mathrm{hcp}-\mathrm{Fe}$ at high pressure: experimental constraints, extrapolations and comparison with seismic models / D. Antonangeli, E. Ohtani // Progress in Earth Planetary Science. - 2015. № 2, 3. - C. 1-11.

15. Badro J. A seismologically consistent compositional model of Earth's core / J. Badro, A.S. Côté, J.P. Brodholt // Proceedings of the National Academy of Sciences of USA. - 2014. - № 111,21 - C. 7542-7545.

16. Biot M.A. Mechanics of Incremental Deformation / M.A. Biot.- New York: Willey, 1965. - 504 c.

17. Dziewonski A.M. Preliminary reference Earth mode / A.M. Dziewonski, D.L. Anderson // Physics of the Earth and Planetary Interiors.- 1981. - № 25, 4. - C. 297-356.

18. Eringen A.C. Elastodynamics. Vol I: Finite motion. Vol II: Linear theory / A.C. Eringen, E.S. Suhubi. - New York: Academic Press, 1974, 1975. $-1018 \mathrm{c}$

19. Guliyev H.H. Analysis of the physical parameters of the Earth's inner core within the mechanics of the deformable body / H.H. Guliyev // Transactions of NAS of Azerbaijan, Issue Mechanics, Series of PhysicalTechnical and Mathematical Sciences. - 2016. - № 36, 7. - C. 19-30.

20. Guliyev H.H. Analysis of results of interpretation of elastic parameters of solid core of the Earth from the standpoint of current geomechanics / H.H. Guliyev // Geophysical Journal. - 2017. - № 39, 1. - C. 79-96.

21. Guz A.N. Fundamentals of the three-dimensional theory of stability of deformable bodies / A.N. Guz. - Berlin : Springer, 1999 - 557 c.

22. Helffrich G. Outer-core compositional stratification from observed core wave speed profiles / G. Helffrich, S. Kaneshima // Nature. - 2010. № 468, 7325. - C. $807-810$.

23. https://ds.iris.edu/spud/earthmodel. Access mode

24. Kennett B.L.N.Constraints on seismic velocities in the Earth from traveltimes / B.L.N. Kennett, E.R. Engdahl, R. Buland // Geophysical Journal International. - 1995. - № 122, 1. - C. 108-124.

25. Kono $Y$. Sound velocities of MORB and absence of a basaltic layer in the mantle transition region / Y. Kono, T. Irifune, H. Ohfuji, Y. Higo, K.-I. Funakoshi // Geophysical Research Letters. - 2012. - № 39. - C. L24306.

26. Kuliev G.G. To elastic waves propagation in strained nonlinear anisotropic media / G.G. Kuliev, M.J. Jabbarov //Proceedings of the ANAS Earth Sciences.- 1998. - № 2. - C. 103-112.

27. LiX. The influence of initial stress on wave propagation and dynamic elastic coefficients / X. Li, M. Tao // Geomechanics and Engineering An International Journal. - 2015.- № 8, 3. - C. 377-390.

28. Liu J. Abnormal acoustic wave velocities in basaltic and ( $\mathrm{Fe}, \mathrm{Al})$ bearing silicate glasses at high pressures / J. Liu, J.-F. Lin // Geophysical Research Letter. - 2014. - № 41. - C. 8832-8839.

29. Mao Z. Sound velocities of hydrous ringwoodite to $16 \mathrm{GPa}$ and $673 \mathrm{~K}$ I Z. Mao, J.-F. Lin, S.D. Jacobsen, T.S. Duffy, Y.-Y. Chang, J.R. Smyth, D.J. Frost, E.H. Hauri, V.B. Prakapenka // Earth and Planetary Science Letters. 2012 - № 331-332 - C. 112-119.

30. Mao Z. Sound velocities of Fe and Fe-Si alloy in the Earth's core / Z. Mao, J.-F. Lin, J. Liu, A. Alatas, L. Gao, J. Zhao, H.-K. Mao // Proceedings of the National Academy of Sciences of USA - 2012 - № 109, 26. C. $10239-10244$

31. Nimmo F. Energetics of the Core", ( $8^{\text {th }}$ Volume), In: Treatise on Geophysics, (2 ${ }^{\text {nd }}$ Edition), (Edited by Schubert G.) / F. Nimmo. - Oxford: Elsevier, 2015. - C. 27-55.

32. Ohtani $E$. Sound velocity of hexagonal close-packed iron up to core pressures / E. Ohtani, Y. Shibazaki, T. Sakai, K. Mibe, H. Fukui, S. Kamada, T. Sakamaki, Y. Seto, S. Tsutsui, A.Q. Baron // Geophysical Research Letter. - 2013. - № 40, 19. - C. 5089-5094.

33. Prescher C. High Poisson's ratio of Earth's inner core explained by carbon alloying / C. Prescher, L. Dubrovinsky, E Bykova, I. Kupenko, K. Glazyrin, A. Kantor, C. VcCammon, M. Mookherjee, Y. Nakajima, N. Miyajima // Nature Geoscience. - 2015. - № 8, 3. - C. 220-223.

34. Sumita I. Inner-Core Dynamics", ( $8^{\text {th }}$ Volume), In: Treatise on Geophysics, (Eited by Schubert, G.) / I. Sumita, M.I. Bergman. - Oxford: Elsevier, 2007. - C. 297-316.

35. Tao $M$. Theoretical and numerical analysis of the influence of initial stress gradient on wave propagations / M. Tao, Z. Chen, X. Li, H. Zhao, T. Yin // Geomechanics and Engineering An International Journal. - 2016. № $10,3 .-$ C. $285-296$.

36. Tateno S. The Structure of Iron in Earth's Inner Core / S. Tateno, K. Hirose, Y. Ohishi, Y. Tatsumi // Science. - 2010. - № 330. - C. 359-361.

37. Thurston $\mathrm{R}$. Third-order elastic constants and velocity of small amplitude elastic waves in homogeneously stressed media / R. Thurston, K. Brugger // Physical Review. - 1964. - № 133, 6A - C. 1604-1610.

38. www.sciencedirect.com/science/referenceworks/9780444538031. [Електроний ресурс]

\section{References}

1. Aleksandrov, K.S., Prodayvoda, G.T., Maslov B.P. (2001). Method for determining nonlinear elastic properties of rocks. Doklady akademii nauk, 380, 1, 109-112. [In Russian].

2. Bullen, K.E. (1978). The Earth's Density. M.: Mir, 422 p. [In Russian]. 
3. Vyzhva, S.A., Maslov, B.P., Prodayvoda, G.T. (2005). Effective elastic properties of nonlinear milti-component geological media. Geophysical Journal, 27, 6, 1012-1022. [In Russian].

4. Guz,A.N. (1986). Elastic waves in bodies with initial stresses, ( ${ }^{\text {nd }}$ Volume). K.: Naukova dumka, 916 p. [In Russian]

5. Guz, A.N. (2004). Elastic waves in bodies with initial (residual) stress. K.: A.C.K., 672 p. [In Russian].

6. Kuliev, G.G., Jabbarov, M.J. (2000). Amplitude characteristics of elastic waves in stressed medium. Doclady Russian Academy of Sciences, 370, 4, 672-674. [In Russian].

7. Maslov, B.P., Prodayvoda, G.T. (1998). Dispersion and scattering of elastic waves in a fractured geological medium. Geophysical Journal, 20, 2 , 47-55. [In Russian]

8. Prodaivoda, G.T., Vyzhva, S.A., Vershilo, I.V. (2012). Mathematical modeling of effective geophysical parameters. K.: Vidavnicho-poligrafichniy tsentr "Kiïvskiy universitet, 287 p. [In Ukrainian]

9. Prodayvoda, G.T., Omelchenko, V.D., Maslov, B.P. (2004). Seismomineralogical model of the Earth's crust of the Ukrainian Shield. Geophysical Journal, 26, 4, 100-107. [In Russian].

10. Truesdell, K. (1975). A first course in rational continuum mechanics. Moscow: Mir, 592 p. [In Russian]

11. Akbarov,S.D. (2015). Dynamics of Pre-Strained Bi-Material Elastic Systems: Linearized Three-Dimensional Approach. Switzerland: Springer, $1004 \mathrm{p}$.

12. Anderson, D.L. (2007). New Theory of the Earth. New York: Cambridge University Press, $400 \mathrm{p}$

13. Anderson, O.L. (1995). Equations of State of Solids for Geophysics and Ceramic Science. New York : Oxford University Press, $432 \mathrm{p}$.

14. Antonangeli, D., Ohtani, E. (2015). Sound velocity of hcp-Fe at high pressure: experimental constraints, extrapolations and comparison with seismic models. Progress in Earth Planetary Science, 2, 3, 1-11.

15. Badro, J., Côté, A.S., Brodholt, J.P. (2014). A seismologically consistent compositional model of Earth's core. Proceedings of the National Academy of Sciences of USA, 111,21, 7542-7545.

16. Biot, M.A. (1965). Mechanics of Incremental Deformation. New York: Willey, $504 \mathrm{p}$.

17. Dziewonski, A.M., Anderson, D.L. (1981). Preliminary reference Earth model. Physics of the Earth and Planetary Interiors, 25, 4, 297-356.

18. Eringen, A.C., Suhubi, E.S. Elastodynamics. Vol I: Finite motion (1974). Vol II: Linear theory (1975). New York: Academic Press, 1018 p.

19. Guliyev, H.H. (2016). Analysis of the physical parameters of the Earth's inner core within the mechanics of the deformable body. Transactions of NAS of Azerbaijan, Issue Mechanics, Series of Physical-Technical and Mathematical Sciences, 36, 7, 19-30.

20. Guliyev, H.H. (2017). Analysis of results of interpretation of elastic parameters of solid core of the Earth from the standpoint of current geomechanics. Geophysical Journal, 39, 1, 79-96.

21. Guz, A.N. (1999). Fundamentals of the three-dimensional theory of stability of deformable bodies. Berlin : Springer, $557 \mathrm{p}$

22. Helffrich, G., Kaneshima, S. (2010). Outer-core compositional stratification from observed core wave speed profiles. Nature, 468, 7325, $807-810$

Г. Кулієв, д-р фіз.-мат. наук, проф., акад. НАНА

E-mail: hatamguliyev@gmail.com,тел.: (+994 12) 5105617

Інститут геології та геофізики НАН Азербайджану

Відділ "Тектонофізика і геомеханіка"

пр. Г. Джавида, 119, Баку, AZ1143, Азербайджан
23. Access mode: https://ds.iris.edu/spud/earthmode

24. Kennett, B.L.N., Engdahl, E.R., Buland, R. (1995).Constraints on seismic velocities in the Earth from traveltimes. Geophysical Journal International, 122, 1, 108-124.

25. Kono, Y., Irifune, T., Ohfuji, H., Higo, Y., Funakoshi, K.-I. (2012). Sound velocities of MORB and absence of a basaltic layer in the mantle transition region. Geophysical Research Letters, 39, L24306.

26. Kuliev, G.G., Jabbarov, M.J. (1998). To elastic waves propagation in strained nonlinear anisotropic media.Proceedings of the ANAS, Earth Sciences, 2, 103-112.

27. Li, X., Tao, M. (2015). The influence of initial stress on wave propagation and dynamic elastic coefficients. Geomechanics and Engineering An International Journal, 8, 3, 377-390.

28. Liu, J., Lin, J.-F. (2014). Abnormal acoustic wave velocities in basaltic and ( $\mathrm{Fe}, \mathrm{Al})$-bearing silicate glasses at high pressures. Geophysical Research Letter, 41, 8832-8839.

29. Mao, Z., Lin, J.-F., Jacobsen, S.D., Duffy, T.S., Chang, Y.-Y., Smyth, J.R., Frost, D.J., Hauri, E.H., Prakapenka, V.B. (2012). Sound velocities of hydrous ringwoodite to $16 \mathrm{GPa}$ and $673 \mathrm{~K}$. Earth and Planetary Science Letters, 331-332, 112-119.

30. Mao, Z., Lin, J.-F., Liu, J., Alatas, A., Gao, L., Zhao, J., Mao, H.-K. (2012). Sound velocities of Fe and Fe-Si alloy in the Earth's core. Proceedings of the National Academy of Sciences of USA, 109, 26, 10239-10244.

31. Nimmo, F. (2015). Energetics of the Core", (8 ${ }^{\text {th }}$ Volume), In: Treatise on Geophysics, ( $2^{\text {nd }}$ Edition), (Edited by Schubert G.). Oxford: Elsevier, 27-55.

32. Ohtani, E., Shibazaki, Y., Sakai, T., Mibe, K., Fukui, H., Kamada, S., Sakamaki, T., Seto, Y., Tsutsui, S., Baron, A.Q. (2013). Sound velocity of hexagonal close-packed iron up to core pressures. Geophysical Research Letter, 40, 19, 5089-5094.

33. Prescher, C., Dubrovinsky, L., Bykova, E., Kupenko, I., Glazyrin, K., Kantor, A., VcCammon, C., Mookherjee, M., Nakajima, Y., Miyajima, N. (2015). High Poisson's ratio of Earth's inner core explained by carbon alloying. Nature Geoscience, 8, 3, 220-223.

34. Sumita, I., Bergman, M.I. (2007). Inner-Core Dynamics", (8 $8^{\text {th }}$ Volume), In: Treatise on Geophysics, (Eited by Schubert, G.). Oxford: Elsevier, 297-316.

35. Tao, M., Chen, Z., Li, X., Zhao, H., Yin, T. (2016). Theoretical and numerical analysis of the influence of initial stress gradient on wave propagations. Geomechanics and Engineering An International Journal, 10, 3, 285-296.

36. Tateno, S., Hirose, K., Ohishi, Y., Tatsumi, Y. (2010). The Structure of Iron in Earth's Inner Core. Science, 330, 359-361.

37. Thurston, R., Brugger, K. (1964). Third-order elastic constants and velocity of small amplitude elastic waves in homogeneously stressed media. PhysicalReview, 133, 6A, 1604-1610.

38. Access mode: www.sciencedirect.com/science/referenceworks/ 9780444538031

Надійшла до редколегії 15.06.17

\section{ПРО ОСОБЛИВОСТІ РОЗПОВСЮДЖЕННЯ ПРУЖНИХ ХВИЛЬ В ІЗОТРОПНИХ СЕРЕДОВИЩАХ ЗА ВИСОКИХ І НАДВИСОКИХ ТИСКІВ}

Дослідження питань поширення пружних хвиль у геологічному середовищі становлять наукову основу обробки та інтерпретаціі комплексу даних сейсморозвідувальних і сейсмологічних робіт.

Мета. Створення більш обгрунтованої теоретичної бази геомеханічної інтерпретації різних груп геофізичних спостереженних та експериментальних даних.

Методика. Некласично-лінеаризований підхід нелінійної еластодинаміки. Ураховуються лінійні та нелінійні малі й великі початкові деформації. Процеси деформації описуються за допомогою різних пружних потенціалів.

Результати. У межах різних варіантів теорії малих і початкових деформацій із застосуванням квадратичного і Мурнаганського типів пружних потенціалів отримано аналітичні залежності параметра тиску і швидкостей поширення пружних хвиль від деформацій без додаткової лінеаризації.

Наукова новизна. Установлено, що існують критичні величини деформації, при досягненні яких в однорідно деформованих пружних ізотропних середовищах не можуть поширюватися пружні поздовжні й поперечні хвилі з речовинною швидкістю. Кількісні значення критичних величин деформацій для поздовжніх і поперечних хвиль відрізняються та істотно залежать від застосованих пружних потенціалів.

Практична значимість. Отримані аналітичні залежності дозволяють синтезувати справжні величини пружних параметрів деформованих середовищ з комплексу сейсморозвідувальних і сейсмологічних даних. Установлення критичних деформацій для швидкостей поздовжніх і поперечних хвиль дозволить запропонувати диференційні критерії щодо розподілу пружних параметрів у теоретичних моделях Землі загалом і окремо в їі різних структурних елементах.

Ключові слова: нелінійна еластодинаміка, пружні хвилі, початкова деформація, швидкості поздовжніх і поперечних хвиль. 
Г. Кулиев, д-р физ.-мат. наук, проф., акад. НАНА

E-mail: hatamguliyev@gmail.com,тел.: (+994 12) 5105617

Институт Геологии и Геофизики НАН Азербайджана

Отдел "Тектонофизика и геомеханика"

пр. Г. Джавида, 119, Баку, AZ1143, Азербайджан

\section{ОБ ОСОБЕННОСТЯХ РАСПРОСТРАНЕНИЯ УПРУГИХ ВОЛН В ИЗОТРОПНЫХ СРЕДАХ ПРИ ВЫСОКИХ И СВЕРХВЫСОКИХ ДАВЛЕНИЯХ}

Исследования вопросов распространения упругих волн в геологической среде составляют научную основу обработки и интерпретации комплекса данных сейсморазведочных и сейсмологических работ.

Цель. Создание более обоснованной теоретической базы геомеханической интерпретации различных групп геофизических наблюденных и экспериментальных данных.

Методика. Неклассически-линеаризированный подход нелинейной эластодинамики. Учитываются линейные и нелинейные малые и большие начальные деформации. Процессы деформации описываются с помощью различных упругих потенциалов.

Результаты. В рамках различных вариантов теории малых и начальных деформаций с применением квадратичного и Мурнаганского типов упругих потенциалов получены аналитические зависимости параметра давления и скоростей распространения упругих волн от деформаций без дополнительной линеаризации.

Научная новизна. Установлено, что существуют критические величины деформации при достижении которых в однородно деформированных упругих изотропных средах не могут распространяться упругие продольные и поперечные волны с вещественной скоростью. Количественные значения критических величин деформаций для продольных и поперечных волн отличаются и существенным образом зависят от применяемых упругих потенциалов.

Практическая значимость. Полученные аналитические зависимости позволяют синтезировать истинные величины упругих параметров деформированных сред из комплекса сейсморазведочных и сейсмологических данных. Установление критических деформаций для скоростей продольных и поперечных волн позволит предложить дифференциальные критерии по распределению упругих параметров в теоретических моделях Земли в целом и в отдельности в ее различных структурных элементах.

Ключевые слова: нелинейная эластодинамика, упругие волны, начальная деформация, скорости продольных и поперечных волн. 